\title{
都市近郊農村に打ける中高年者の労働負担と健康 とくに血液性状との関連に関する研究
}

\section{一広島県都市近郊農村について—}

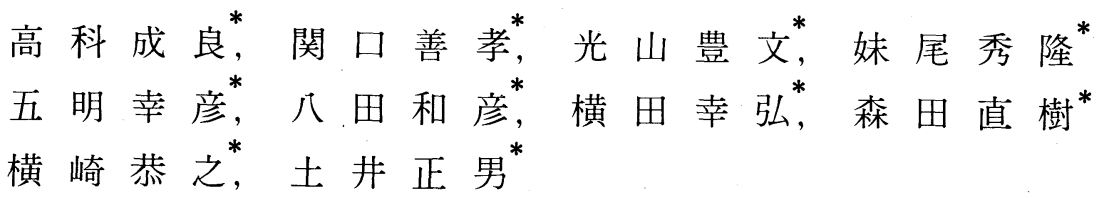

は じめに

農村の労働力は若年層の流出により，中高年層とく に婦人と高令者に頼らざるを得なくなっているのが現 状である。農村に括ける労働負担が中高年層の人達の 健康状態にいかなる影響を与えているかについての調 査研究は数少ない上らである。そこで, 広島県都市近 郊農村に居住する中高年者を対象にして，昭和55年よ り昭和 57 年までの 3 年間に労働負担と健康状態の関連 について調査した成績を報告する。

\section{研 究 成 績}

\section{I 調査対象地域および農業経営耕地面積}

調査対象地域は広島県全般にわたる都市近郊農村で あり, 対象地域の経営耕地面積の平均は表 1 に示した が, 経営耕地面積は広島県ではほぼ平均值に近いけれ

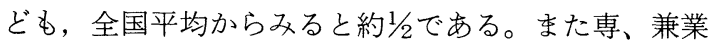
別にみると専業農家 1 に対し, 第 1 種兼業農家は 0.76 , 第 2 種兼業農家は7.12の割合である。

\section{II アンケートによる生活行動身体状況調査}

アンケート調査を実施した地域は, 広島市最北端に 位置する農業地帯で (人口 18,312 人。総戸数 5247 戸) であり, 対象は安佐町農業協同組合に所属する40才よ り69才までの農業従事者 1893 人（男性 901 人，女性 992 人、回収率 $90 \%$ ）と 70 才以上の 280 人（男性 162 人, 女 性 118 人, 回収率 $88 \%$ である。（表 2 ）。

また40才より60才までの調査対象者の農業経営耕地 面積の平均は表 3 に示したように，水田が主で畑がそ れにつぎ，いずれも専業，第 1 種兼業，第 2 種兼業の 順に耕地面積は少なくなって掞り，果樹・八ウス栽培 等は少なく, 皇家もごく一部の農家で豚, 乳牛, 肉牛，とり等が少数あつかわれているのみであった。

*広島県厚生連 廣島総合病院 内科

また家族構成をみると，その平均は専農で 3,2 人， 1 種 兼業で 5.0 人， 2 種兼業で 3.8 人であった。

（1）40才ょり69才までの農業従事者に対する調査成績 生活. 労働, 身体状況成績は表 4 打よび表 5 に一括 して示した。

農業へのかかわり方では, 農業の主なる担い手は男 女とも加令とともに増加して打り，40，50才代では男 性より女性の方が多い上らであった。

農作業時間の平均値をみると, 農繁期には男女とも 50 才代がもっとも長く, 農閑期の農作業時間は農繁期 より約 2 時間短く, 男女とも，50，60才代に比べて 40 才代の作業時間は短いようであった。

睡眠時間では, 農繁期の方が農閑期よりやや長く, また両期とも男性は女性より約 1 時間睡眠時間が長い

表 1. 平均農業経営耕地面積

\begin{tabular}{c|lcc}
\hline 総 面 積 & 水田 & 畑 & 果樹 \\
\hline 44.4 & 32.4 & 6.8 & 5.2 \\
& $\begin{array}{l}\text { 単位:アール } \\
\text { M }\end{array}$ &
\end{tabular}

表 2.アンケート調查対象

\begin{tabular}{c|cccc:c}
\hline 年 令 & 40 歳代 & 50 歳代 & 60 歳代 & 計 & 70歳以上 \\
\hline 男性 & 248 & 364 & 289 & 901 & 162 \\
女 性 & 311 & 390 & 291 & 992 & 118 \\
\hline 計 & 559 & 754 & 580 & 1,893 & 280
\end{tabular}

表 3. 専 - 兼別, 耕地面積

\begin{tabular}{|c|c|c|c|c|}
\hline 耕 地 & 水田 $(\mathbf{a})$ & 畑 (a) & 果樹 (a) & ハウス栽培 $(\mathbf{a})$ \\
\hline 専業 & 52.3 & 9.6 & 3.5 & 4.5 \\
\hline 1 種兼農 & 40.8 & 10.8 & 14.4 & 0 \\
\hline 2 種兼農 & 32.3 & 10.1 & 6.4 & 2.5 \\
\hline
\end{tabular}


表 4 . 農業従事者の生活, 労働, 身体状況調査

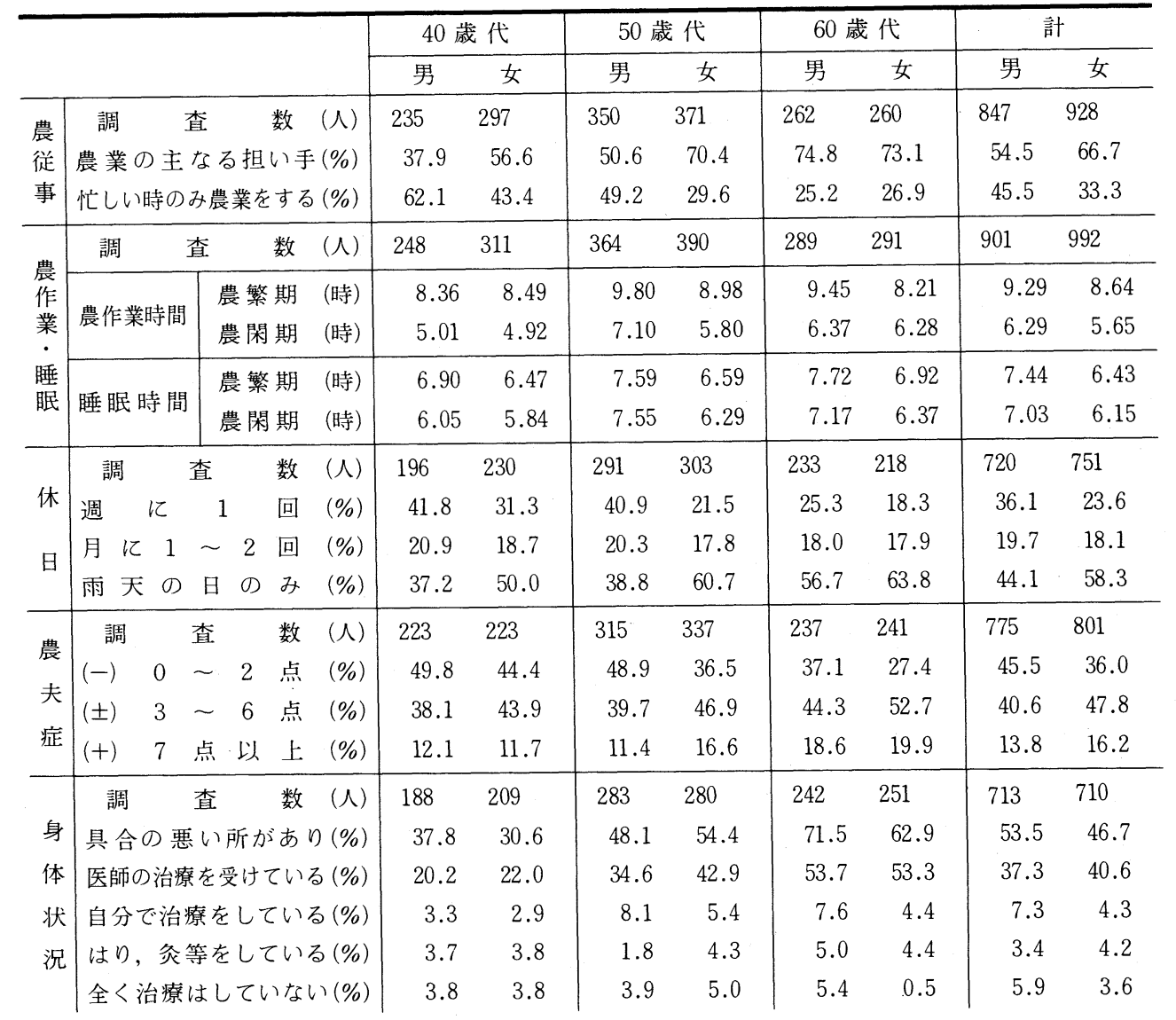

傾向がみられた。

農夫症調査では，陽性者は各年代，男女とも $20 \%$ 以 下であったが, 腰痛, 肩こり, 夜間頻尿が訴光として は多かった。

調査時の身体状況についてみると, 体調の悪いもの がかなり多く, 男女とも加令と相関して抢り，40才代 の女性が $30.6 \%$ で最低，60才代の男性が $71.5 \%$ で最高 であった。体調の悪いものの大半は医師の治療を受け ているが, 自分で治療したり, 放置しているものが各 年代に少数みられた。

罹病疾患について回答を得たものを表 5 に一括表示 したが, 循環器疾患, 消化器疾患, 代謝疾患, 骨・関 節疾患が比較的多くみられた。

（2）高令者（70才以上）の生活, 労働, 身体状況調査 成績

高令者（70才以上）に対するアンケート調査の結果 を表 6 に示した。
起床時間は男女とも午前 $6 \sim 7$ 時が大半をしめ, 就 寝時間は男女とも午前 $9 \sim 10$ 時がもっとも多かった。

日中の労働についてみると, 男女とも約 $80 \%$ が実施 しており，労働時間は男性では $4 \sim 6$ 時間が，女性で は $2 \sim 4$ 時間が多く, 労働内容は男女とも農作業が もっとも多かった。

役職についているものは比較的少なく，とくに女性 では $20 \%$ 弱であり，その種類では老人会が多いようで あった。老人クラブへの積極的参加は比較的少なく, 全く参加しないものもかなりみられた。

体調についてみると，男女とも体調が悪いと答光た ものは約 $75 \%$ あ, 悪い部位は腰, 肩, 四肢, 胃腸な どが多いようであった。

風邪については「ひきやすい」と答えた男女とも $20 \%$ 弱で比較的少なく, 易疲労性は男女とも $30 \%$ 強あり, 食欲不振を訴えるものは少なかった（6〜 7\%）。 飲酒では，女性の約 $80 \%$ に飲酒の習慣がないのに反 
表 5 . 疾 病調査結果

\begin{tabular}{|c|c|c|c|c|c|c|c|c|}
\hline 代 & & & & & & & & \\
\hline 性 & 男 & 女 & 男 & 女 & 男 & 女 & 男 & 女 \\
\hline 核 & 1 & 1 & 1 & & 2 & & 4 & 1 \\
\hline 発疹を伴うビールス疾患 & & & & 1 & & & & 1 \\
\hline 甲 状 腺 の 疾 患 & & 1 & & 1 & & & & 2 \\
\hline 糖 & 4 & 1 & 9 & 1 & 10 & 5 & 23 & 7 \\
\hline 貧 & 1 & 2 & 1 & 9 & 2 & 6 & 4 & 17 \\
\hline 精 神 分 裂 病 & & 1 & & & & 2 & & 3 \\
\hline 神 & 5 & 1 & 13 & 1 & 1 & 1 & 19 & 3 \\
\hline 視 器 の 疾 患 & 2 & 1 & 1 & 7 & 6 & 22 & 9 & 30 \\
\hline 聴 器 $の$ 疾 患 & 1 & & 2 & 1 & & 1 & 3 & 2 \\
\hline リュウマチ性心臓病 & & & & 2 & 1 & & 1 & 2 \\
\hline 高 血 圧 性 疾 患 & 7 & 15 & 21 & 34 & 28 & 36 & 56 & 85 \\
\hline 虚 血 性 心 臟 病 & & & & 5 & 1 & 10 & 1 & 15 \\
\hline その他の心臟 病 & 3 & & 9 & & 11 & 7 & 23 & 7 \\
\hline 脳 血 管 障 害 & & & & 1 & 2 & 4 & 2 & 5 \\
\hline 気 管 支 & & 2 & & & & & & 2 \\
\hline 慢 性 気 管 支 炎 & 1 & & & & 1 & & 2 & \\
\hline 喘 & 1 & & 2 & & 2 & & 5 & \\
\hline 歯 $の$ 疾 患 & 2 & & 1 & 1 & 1 & & 4 & 1 \\
\hline 胃 ·十二指腸 潰 瘍 & 2 & 1 & 19 & & 19 & & 40 & 1 \\
\hline 胃 & 12 & 5 & 3 & 14 & 7 & 12 & 22 & 31 \\
\hline 疾 & 7 & 1 & 2 & 5 & 5 & 4 & 14 & 10 \\
\hline 炎 & 1 & & 2 & 3 & 2 & 1 & 5 & 4 \\
\hline 女 性 性 器 疾 患 & & & & & & 1 & & 1 \\
\hline 皮下組 織 の疾患 & & & & & & 1 & & 1 \\
\hline 慢性 関節リュウマチ & 5 & 13 & 6 & 14 & 9 & 28 & 20 & 55 \\
\hline 痛 & 14 & 21 & 14 & 33 & 32 & 38 & 60 & 92 \\
\hline その他の春柱 疾患 & 3 & & 3 & 1 & 3 & & 9 & 1 \\
\hline 骨 & & & & & 2 & & 2 & \\
\hline 自 動 車 事 故 & & & & 1 & & & & 1 \\
\hline
\end{tabular}

し，男性では約70\%が毎日あるいは時々飲酒している

趣味については，男女とも趣味をもつ人は半数以下 といら結果を得た。

䒜煙についてみると,女性のほとんどと,男性の $55 \%$ にその習慣がみられなかった。

病気の有無では, 男女とも約 $70 \%$ は何らかの疾患を 有し, 種類は循環器疾患, 骨・関節疾患, 白内障など が多いよらであった。

疾患に対する治療は汇とんどの人が受けているよう であり, 薬もかなりの人が服用しているようであった。

生活と健康についてみると, 体動が不自由と考光ら れる人は男性 12 人 (7.4\%), 女性 11 人 (9.3\%)であり, その原因は心臓病, 神経痛, 肝臟病, 半身不随などで あった。

であり，テレビはかなりよくみているようであった。

III 都市近郊農村居住者の労働時間別医学的調査成績 ならびに栄養摄取状態の比較

都市近郊農村居住者で昭和 55 年度より昭和 57 年度ま での 3 年間に, 労働時間調査, 医労的調査および栄養 摂取調査を同時に実施することができたものについて 検討した。

(1) 対象

対象は表 7 に示したよらに，30才代より60才代にわ たる男性233例，女性465例であった。

(2) 調查方法 
表 6 . 高齢者（70歳以上）の生活・健康調査

\begin{tabular}{|c|c|c|c|c|c|c|c|c|c|c|c|}
\hline & & 生 活 調 & 周 査 & & & & 健 & 康 & 調 & & \\
\hline (1) 起 & 床 & 時 間 & 男 (162) & 女(118) & (6) 体 & 調 & 男 (162) & 女(118) & (15) 生活と健康 (人) & 男 & 女 \\
\hline & 5 & 時 前 & 1.2 & 1.7 & & 悪 い $(\%)$ & 75.3 & 77.1 & 普通の生活 & 35 & 31 \\
\hline & 5 & $\sim$ & 8.6 & 11.0 & & 腰 & 53 & 44 & 普通の仕事 & 27 & 37 \\
\hline & 6 & $\sim$ & 54.2 & 51.7 & 悪 & 肩 & 30 & 27 & 家 事 程 度 & 31 & 25 \\
\hline & 7 & $\sim 8$ & 30.2 & 28.0 & & 手足のしびれ & 27 & 30 & 体が悪く働けぬ & 6 & 1 \\
\hline & 8 & $\sim 9$ & 5.6 & 7.6 & & & 23 & 7 & 仕事せずぶら & 15 & 10 \\
\hline & & 計 $(\%)$ & 100 & 100 & $(1)$ & 湿 & 5 & 3 & 寝たり起きたり & 11 & 9 \\
\hline (2) 就 & 寝 & 時 間 & & & & $\begin{array}{lll}\text { 韻 } & & \text { 里 } \\
\text { そ } & \text { の } & \text { 他 }\end{array}$ & $\begin{array}{l}17 \\
41\end{array}$ & $\begin{array}{l}13 \\
19\end{array}$ & 寝たきり & 1 & 2 \\
\hline & 7 & 時 〜 & 4.9 & 2.5 & & ぜをひき & & & 葠 心 臓 病 & 2 & 1 \\
\hline & 8 & $\sim$ & 17.9 & 29.7 & (7) & やすい $(\%)$ & 19.8 & 16.1 & $\begin{array}{c:c}\text { だ } & \text { 神 経 痛 }\end{array}$ & 2 & 5 \\
\hline & 9 & $\sim$ & 50.0 & 44.1 & (8) 疲 & れやすい $(\%)$ & 31.5 & 34.7 & $\begin{array}{l:ll}\text { 起 } & \text { 肝 臓 病 } \\
\text { き }\end{array}$ & 1 & 1 \\
\hline & $\begin{array}{l}10 \\
11\end{array}$ & $\sim$ & 6.2 & $\begin{array}{r}21.2 \\
2.5\end{array}$ & (9) 食 & 欲なし $(\%)$ & 6.2 & 7.6 & 半身不随 & 1 & 2 \\
\hline & & & & & (10) & 毎 & 40.1 & 5.1 & (人) そ の 他 & 6 & 2 \\
\hline & & $(\%)$ & 100 & 100 & 领 & 時 & 30.3 & 16.9 & (16) 趣味あり $(\%)$ & 42.0 & 31.4 \\
\hline (3) 日 & 中： & 并働あり & 80.9 & 82.2 & $\begin{array}{l}\text { 酒 } \\
(\%)\end{array}$ & 飲 ま ぬ & 29.6 & 78.0 & & 19 & 7 \\
\hline 兴 & 2 & 時 間 内 & 13.0 & 15.5 & & 20本以上 & 3.7 & 0 & & 13 & 0 \\
\hline 働 & 2 & $\sim$ & 29.0 & 36.1 & & $10 \sim 20$ & 20.4 & 0 & & 4 & 0 \\
\hline $\begin{array}{l}\text { 時 } \\
\text { 間 }\end{array}$ & 4 & $\sim$ & 33.6 & 27.8 & 煙 & 10 本下 & 20.4 & 0.8 & 種 & 5 & 1 \\
\hline & 6 & $\sim$ & 24.4 & 20.6 & $(\%)$ & $\begin{array}{l}10 \text { 本以下 } \\
\text { すわ如 }\end{array}$ & $\begin{array}{l}20.4 \\
55.5\end{array}$ & 1.7 & & 1 & 5 \\
\hline & & 計 $(\%)$ & 100 & 100 & & & & 97.5 & 茶 & 0 & 1 \\
\hline & & 作 業 & 102 & 61 & (12) 病 & 気あり & 69.1 & 72.9 & 旅行 & 31 & 10 \\
\hline 労 & 内 & 職 & 1 & 0 & & 糖 尿 病 & 17 & 2 & テ レ ビ & 40 & 21 \\
\hline 働 & 家 & 事 & 10 & 20 & & & 15 & 14 & 音 楽 鑑 賞 & 3 & 2 \\
\hline 容 & 盆 & 栽 & 6 & 1 & 種 & 高 血 圧 & 37 & 32 & 盆栽園芸 & 15 & 3 \\
\hline (人) & & 庭菜 園 & 22 & 30 & & 緑 内 障 & 2 & 3 & そ の 他 & 12 & 7 \\
\hline & & の & 15 & 14 & 類 & 白内 障 & 20 & 25 & (17) テ レ ビ $(\%)$ & & \\
\hline (4) 役 & 暗 & 我 有 $(\%)$ & 35.2 & 19.5 & & リウマチ & 3 & 10 & 1 時 間 位 & 8.3 & 27. \\
\hline & & 人 会 & 37 & 18 & (人) & 神 経 痛 & 36 & 31 & 2 時 間 位 & & 25 \\
\hline & & 治 会 & 14 & 0 & & 喘 & 7 & 0 & & 35.6 & \\
\hline (人) & & 人 & 0 & 3 & & そ の 他 & 24 & 9 & & & \\
\hline & & 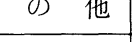 & & 2 & (13)医追 & 師治療あり $(\%)$ & 59.9 & 68.6 & & & \\
\hline $\begin{array}{l}(5) \\
\text { 老 }\end{array}$ & & $<$ 参 加 & 34.0 & 28.0 & (14)薬 & 時 & 45.7 & 46.6 & & & \\
\hline 至 & & きに参加 & $\begin{array}{l}40.1 \\
25.9\end{array}$ & $\begin{array}{l}38.1 \\
33.9\end{array}$ & 服 & & 33.3 & 31.4 & & & \\
\hline & & & & & 170 & & & & & & \\
\hline
\end{tabular}

表 7. 対象

\begin{tabular}{|c|c|c|c|c|c|c|c|c|c|c|c|c|c|}
\hline 年 代 & \multicolumn{4}{|c|}{40 歳 代 } & \multicolumn{4}{|c|}{50 歳 代 } & \multicolumn{4}{|c|}{60 歳 代 } & \multirow{2}{*}{ 総計 } \\
\hline 労働時間 & $4 \geqq$ & $4 \sim 8$ & $8 \leqq$ & 小計 & $4 \geqq$ & $4 \sim 8$ & $8 \leqq$ & 小計 & $4 \geqq$ & $4 \sim 8$ & $8 \leqq$ & 小計 & \\
\hline 男 性 & 24 & 20 & 41 & 85 & 19 & 18 & 54 & 91 & 7 & 26 & 24 & 57 & 233 \\
\hline 女 性 & 24 & 73 & 95 & 192 & 19 & 83 & 92 & 194 & 10 & 31 & 38 & 79 & 465 \\
\hline
\end{tabular}


表 8. 検査各項目の測定法と正常値

\begin{tabular}{|c|c|c|}
\hline 項 & 法 & 常 \\
\hline 満 & Body Mass Index & 'BM I \\
\hline 肥 満 傾 向 & $"$ & $24.0 \sim 25.9$ \\
\hline ヘモグロビン & シアンメトヘモグロビン & 男性 13 18g/dl, 女性 12 15 g/dl \\
\hline ヘマトクリット & 電気抵抗法 & 男性 42～52\%，女性 35～45\% \\
\hline コレステロール & 酵素法 (CE-COD-POD系) & $140 \sim 240 \mathrm{mg} / \mathrm{dl}$ \\
\hline 中 性 脂 肪 & 酵素法 (LPL-GK-GPO-POD系) & $40 \sim 160 \mathrm{mg} / \mathrm{dl}$ \\
\hline 燐脂 質 & 酵素法（PLD-COD-POD系） & $130 \sim 260 \mathrm{mg} / \mathrm{dl}$ \\
\hline HDL-コレステロール & 燐タングステン酸 $\mathrm{MgCl}_{2}$ 法 & 男性 $33 \mathrm{mg} / \mathrm{dl} \leqq$ ，女性 $35 \mathrm{mg} / \mathrm{dl} \leqq$ \\
\hline $\begin{array}{lll}\mathrm{L} & \mathrm{D} & \mathrm{L}\end{array}$ & ヘパリン $\mathrm{CaCl}_{2}$ 比濁法 & $200 \sim 600 \mathrm{mg} / \mathrm{dl}$ \\
\hline $\begin{array}{llll}\mathrm{V} & \mathrm{L} & \mathrm{D} & \mathrm{L}\end{array}$ & " & $20 \sim 150 \mathrm{mg} / \mathrm{dl}$ \\
\hline カイロミクロン & $"$ & $60 \mathrm{mg} / \mathrm{dl} \geqq$ \\
\hline B $\quad$ U $\quad N$ & ウレアーゼ・インドフェノール法 & $20 \mathrm{mg} / \mathrm{dl} \geqq$ \\
\hline クレアチ = ン & ヤッフェ変法 & $1.2 \mathrm{mg} / \mathrm{dl} \geqq$ \\
\hline 総蛋 白 & ビューレット法 & $6.5 \sim 9.0 \mathrm{~g} / \mathrm{dl}$ \\
\hline アルブミン & ブロム・クレゾール・グリーン法 & $3.5 \sim 6.0 \mathrm{~g} / \mathrm{dl}$ \\
\hline ビリルビン & アルカリ・アゾビリルビン・ブルー法 & $0 \sim 1.4 \mathrm{mg} / \mathrm{dl}$ \\
\hline $\begin{array}{lll}Z & \mathrm{~T} & \mathrm{~T}\end{array}$ & 消化器病学会, 肝機能研究班標準法 & $1.0 \sim 12.0$ 単位 \\
\hline $\mathrm{G} \quad \mathrm{O}$ & I F C C 変法 & $8 \sim 50$ 単位 \\
\hline $\mathrm{G} \quad \mathrm{P}$ & I F C C 変 法 & $8 \sim 50$ 単位 \\
\hline $\mathrm{L} \quad \mathrm{D} \quad \mathrm{H}$ & $\mathrm{UV} \cdot$ Rate 法 $(\mathrm{P} \rightarrow \mathrm{L})$ & $100 \sim 250$ 単位 \\
\hline アル・ホス & カインド・キング法 & $3.0 \sim 11.0 \mathrm{KAU}$ \\
\hline $\begin{array}{lll}\mathrm{L} & \mathrm{A} & \mathrm{P}\end{array}$ & ロイシンアミドを基質とする方法 & 男性 60 230 GRU, 女性 70 190 GRU \\
\hline コリンエステラーゼ & 酵素法 ( $\triangle \mathrm{PH}$ 亿換算 $)$ & $0.61 \sim 1.10 \triangle \mathrm{PH}$ \\
\hline$\gamma-\mathrm{G} \mathrm{T} P$ & Rate 法（可視部吸光測定） & 男性 10 50 IU /1, 女性 7 40 IU /1 \\
\hline 血糖 & グルコース・オキシダーゼ法 & 空腹時 $70 \sim 109 \mathrm{mg} / \mathrm{dl}$ \\
\hline Atherogenic Index & - & $5.5 \leqq$ \\
\hline 心電図虚血性変化 & ミネソタコードによる & \\
\hline $75 \mathrm{~g}$ O G T T 判定 & 日本糖尿病学会診断基準による & \\
\hline 高 血 圧 & WHO 基準による & \\
\hline 神 経 症 傾 向 & CMI 深町判定基準のII · IV 型 & \\
\hline よくうつ症 & Self-rating Depression Scale & \\
\hline
\end{tabular}

労働時間調查は聞きとりにより実施し, 労働時間は 農業 1 亿対し家事 $1 / 2$, 事務 $1 / 3$ として計算し, 労働時間 が 4 時間>，4〜8 時間， 8 時間<の 3 群に分類した。

医学的調査については身体計測, 血圧, 心電図, 検 尿, 検便, 75 gOGTT, 血液一般検查, 血液生化学的検 查, CMI とSDSによる性格テストならびに農夫症テ ストを実施し，各項目の異常率と平均值をもとめて比 較した。異常率については各群の年令構成が同一でな いので総府統計局「昭和 55 年度国勢調查による人口」 を標準として訂正率を算出し使用した。各検查項目の 測定法，正常值ならびに診断基準等は一括して表 8 に 示した。な拈50gOGTTを実施したものについては, 血
糖を $75 \mathrm{gOGTT}$ の血糖値に換算して判定した。

(3) 成績

労働時間と医学的調查成績との関連を表 9 に示し た。労働時間を 4 時間以下, $4 \sim 8$ 時間， 8 時間以上 の 3 群に分類して性別に各検査項目の異常率をを比較 した。

男性についてみると，労働時間 4 時間以下の群で肥 満, 高脂血症, 高コレステロール血症, 高中性脂肪血 症, 高 LDL, 高 VLDL, 高カイロミクロン, 糖尿病, 明らかな肝障害, $\mathrm{ZTT}$ 上昇, GOT 上昇, $\mathrm{LDH}$ 上昇, $\gamma$-GTP 上昇, 上くうつ症, 動脈硬化性血管障害危険 因子（肥満，高血圧，高へマトクリット血症，高脂血 
表 9. 性別 - 労働時間別医学的調查成績 (異常率)

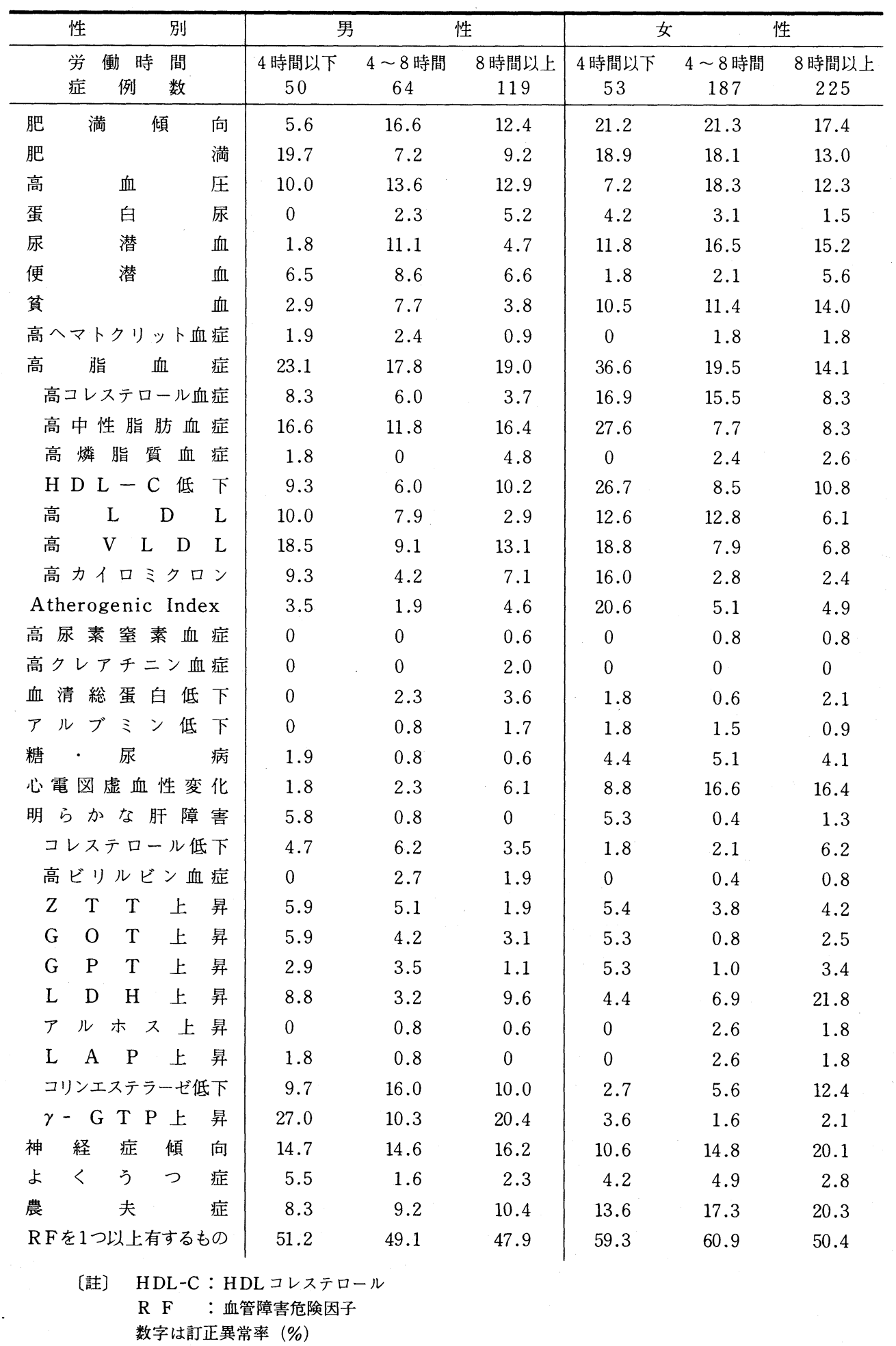


表10. 性別・労働時間別医学的調查成績（平均値）

\begin{tabular}{|c|c|c|c|c|c|c|c|}
\hline 性 & 別 & & & 性 & 女 & & 性 \\
\hline 働 時 & 間 & 4 時間以内 & 4 ～8 時間 & 8 晆間以上。 & 4 時間以内 & & \\
\hline 例 & 数 & 50 & & 119 & 53 & 187 & 225 \\
\hline M & & $.2 \pm 0.44^{*}$ & 31 & $22.0 \pm 0.23$ & $23.2 \pm 0.52$ & $.28^{\Delta}$ & $22.6 \pm 0.19$ \\
\hline 収 縮 期 血 圧 & $(\mathrm{mm} \mathrm{Hg})$ & $129 \pm 2.5$ & $32 \pm 2.2$ & $3 \pm 1.8$ & $132 \pm 2.5$ & $137 \pm 1.5$ & $135 \pm 1.4$ \\
\hline 拡 張 期 血 圧 & $(\mathrm{mm} \mathrm{Hg})$ & $78 \pm 1.6$ & $80 \pm 1.4$ & $30 \pm 1.0$ & $77 \pm 1.5$ & $79 \pm 0.9$ & $78 \pm 0.8$ \\
\hline 色 & $(\mathrm{g} / \mathrm{dl})$ & $15.7=$ & $15.0=$ & $0 \pm 0.12$ & $13.1 \pm 0.18$ & $13.2 \pm 0.09$ & $1 \pm 0.10$ \\
\hline ヘマトクリット & $(\%)$ & $46.0 \pm 0.48^{\times}$ & $43.3 \pm 0.90$ & $44.2 \pm 0.32$ & $38.6 \pm 0.49$ & $39.2 \pm 0.22$ & $38.9 \pm 0.26$ \\
\hline コレステロール & $(\mathrm{mg} / \mathrm{dl})$ & $188 \pm 4.7$ & 3 & 2.8 & & 2.8 & $=2.5$ \\
\hline 中 性 脂 肪 & $(\mathrm{mg} / \mathrm{dl})$ & $118 \pm 9.5$ & $99 \pm 6.3$ & $107 \pm 7.2$ & $126=$ & $103 \pm 4.7$ & $93 \pm 3.3$ \\
\hline 脂 & $(\mathrm{mg} / \mathrm{dl})$ & $191 \pm$ & 190 & 2.6 & 197 & & \\
\hline $\mathrm{H} D \mathrm{D}-\mathrm{C}$ & $(\mathrm{mg} / \mathrm{dl})$ & $45 \pm 1.6$ & $48 \pm 1.6$ & $\pm 1.2^{*}$ & $44 \pm 1.5$ & $49=$ & $50 \pm 0.9^{* *}$ \\
\hline $\mathrm{D}$ & $(\mathrm{mg} / \mathrm{dl})$ & $431 \pm 14.7$ & $404 \pm 13.4$ & $419 \pm 9.2$ & 5.6 & $.7^{\Delta}$ & $428 \pm 8.1$ \\
\hline $\begin{array}{llll}\mathrm{V} & \mathrm{L} & \mathrm{D} & \mathrm{L}\end{array}$ & $(\mathrm{mg} / \mathrm{dl})$ & $92 \pm 10.3^{x}$ & $65 \pm 6.6$ & $4 \pm 7.3$ & $100 \pm 9.9^{x}$ & 76 & $62 \pm 3.7$ \\
\hline カイロミクロン & $(\mathrm{mg} / \mathrm{dl})$ & $28 \pm 3.9$ & $22 \pm 2.6$ & \pm 2.8 & $.1^{*}$ & .2 & 1.6 \\
\hline Atherogenic Ind & & $3.6 \pm 0.18$ & $3.0=$ & .11 & $3.9 \pm 0.22$ & & 99 \\
\hline 尿 素 窒 & (mg & $12 \pm 0.9$ & & & 0.3 & $11 \pm 0.2^{x}$ & $11 \pm 0.2^{*}$ \\
\hline クレアチニン & $(\mathrm{mg} / \mathrm{dl})$ & $0.85 \pm 0.002$ & $0.79 \pm 0.017$ & $0.82 \pm 0.012$ & $0.64 \pm 0.014$ & $0.67 \pm 0.009$ & 0.007 \\
\hline 血清総蛋白 & $(\mathrm{g} / \mathrm{dl})$ & $7.5 \pm 0.06$ & 7.4 & .04 & 7.6 & & $=0.03$ \\
\hline アルブミン & $(\mathrm{g} / \mathrm{dl})$ & $4.2 \pm 0.04$ & 4.1 & 0.03 & $4.1 \pm 0.04^{*}$ & $4.1 \pm 0.02^{\Delta \Delta}$ & $4.0 \pm 0.02$ \\
\hline $\begin{array}{l}75 \\
\mathrm{~g}\end{array}$ & $(\mathrm{mg} / \mathrm{dl})$ & ${ }^{*}$ & $90 \pm$ & 1.3 & & & 1.5 \\
\hline$\stackrel{\mathrm{G}}{\mathrm{O}} 1$ 時間血糖 & $(\mathrm{mg} / \mathrm{dl})$ & $158 \pm 7.0$ & $165=$ & $5 \pm 4.5$ & & & 3.6 \\
\hline $\begin{array}{l:l}\mathrm{T} & 2 \text { 時間血糖 }\end{array}$ & $(\mathrm{mg} / \mathrm{dl})$ & \pm 5.3 & 100 & $92 \pm 3.3$ & $118 \pm$ & 119 & $109 \pm 3.3$ \\
\hline ビ・リルビン & $(\mathrm{mg} / \mathrm{dl})$ & $0.65 \pm 0.042$ & $0.62 \pm 0.036$ & $0.64 \pm 0.032$ & $0.45 \pm 0.028$ & $0.51 \pm$ & $0.49 \pm 0.016$ \\
\hline $\mathrm{T}$ & (単位) & $5.8 \pm 0.42$ & $5.9 \pm 0.42$ & $6.4 \pm 0.28$ & 34 & $7.3 \pm 0.21^{\Delta}$ & .22 \\
\hline G & （単仡 & $22 \pm 1.9$ & $23 \pm$ & 0.8 & $20 \pm 2.4^{*}$ & $20 \pm 2.3$ & $28 \pm 1.7^{*}$ \\
\hline G & (単位) & $21 \pm 1.7$ & $21 \pm 2.3$ & 0.9 & $20 \pm 3.3$ & $16=$ & \\
\hline $\mathrm{D}$ & (単位) & $182 \pm 5.7$ & $191 \pm 4.1$ & $201 \pm 4.2^{*}$ & $183 \pm 4.1$ & & \\
\hline アル木 & $(\mathrm{KAU})$ & $5.9 \pm 0.26$ & $6.4 \pm 0.38$ & $5.7 \pm 0.17$ & $5.8 \pm 0.26$ & $5.7 \pm 0.20$ & $5.7 \pm 0.14$ \\
\hline A & ( GRU) & $124 \pm 4.8$ & $127 \pm 8.1$ & $123 \pm 2.6$ & $108 \pm 3.8$ & $116 \pm 4.9$ & $113 \pm 2.1$ \\
\hline コリンエステラーゼ & $(\triangle \mathrm{PH})$ & $0.91 \pm 0.024$ & $0.82 \pm 0.028$ & $0.82 \pm 0.017$ & $0.91 \pm 0.021^{*}$ & $0.87 \pm 0.011$ & $0.85 \pm 0.012$ \\
\hline$\gamma-\mathrm{G} T \mathrm{P}$ & $(\mathrm{IU} / 1)$ & $43 \pm 5.5$ & $42 \pm 14.7$ & $30 \pm 2.6$ & $20 \pm 2.4$ & $17 \pm 1.1$ & $16 \pm 0.2$ \\
\hline
\end{tabular}

【註〕 BM I : Body Mass Index

HDL-C : HDL コレステロール

* : 労働時間 4 時間以内群と 8 時間以上群間の有意差 $(*: \mathrm{P}<0.05, \quad * *: \mathrm{P}<0.01)$

$x$ : 労働時間 4 時間以内群之 $4 \sim 8$ 時間群間の有意差 $(x: \mathrm{P}<0.05, \quad x \times: \mathrm{P}<0.01)$

$\Delta:$ 労働時間 $4 \sim 8$ 時間群之 8 時間以上群間の有意差 $(\Delta: \mathrm{P}<0.05, \Delta \triangle: \mathrm{P}<0.01)$

症, 糖尿病, 心電図虚性変化： $\mathrm{RF}$ と略)を 1 つ以上有 するものが他群より高率であった。労働時間 $4 \sim 8$ 時 間の群では肥満傾向, 高血圧, 尿潜血陽性, 便潜血陽 性, 貧血, コレステロール低下, 高ビリルビン血症 GPT 上昇, コリンエステラーゼ低下が他群より高率にみら れた。労働時間 8 時間以上の群では尿蛋白, 高燐脂質
血症, HDL コレステロール低下, Atherogenic Index 異常, 血清総蛋白低下, 心電図虚血性变化, 神経症傾 向，農夫症陽性が他群より高率であった。

女性についてみると, “労働時間 4 時間以下の群では 肥満, 蛋白尿, 高脂血症, 高コレステロール血症, 高 中性脂肪血症, HDL コレステロール低下，高 VLDL， 
表11。栄養摂 取 量

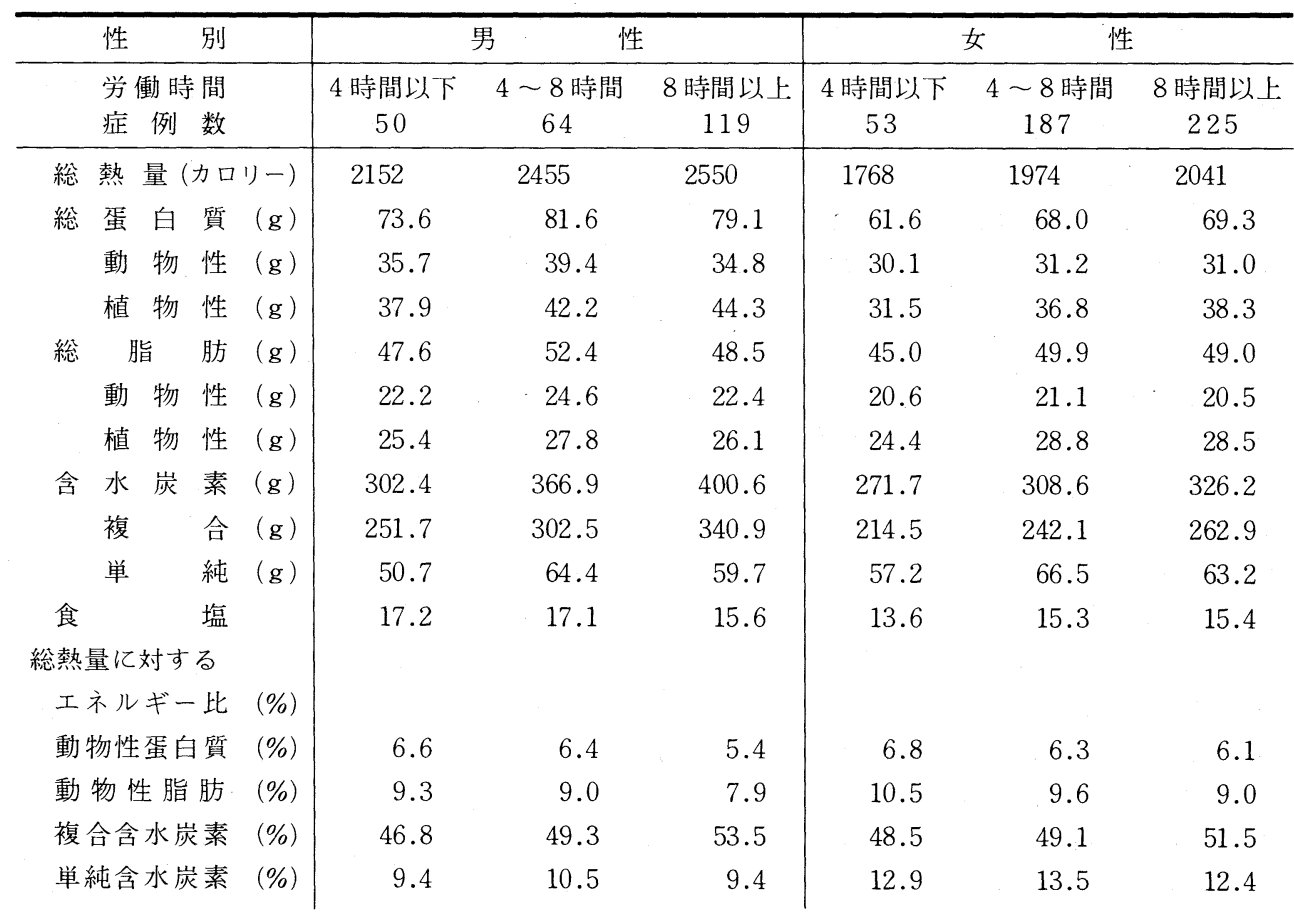

高カイロミクロン, Atherogenic Index 異常, 明らか な肝障害, ZTT 上昇, GOT 上昇, GPT 上昇, $\gamma$-GTP 上昇が他群より高率であった。労働時間 $4 \sim 8$ 時間の 群では, 。肥満傾向, 高血圧, 高 $\mathrm{LDL}$, 糖尿病, 心電図 虚血性変化，上くうつ症, RF を 1 つ以上有するものが 他群より高率にみられた。労動時間 8 時間以上の群で は尿潜血陽性, 便潜血陽性, 貧血, 高燐脂質血症, 二 レステロール低下, $\mathrm{LDH}$ 上昇, コリンエステラーゼ低 下，神経痛傾向，農夫症異常が他群より高率であった。

各調査項目の平均値を表10に示したが、労働時間別 異常率とほぼ同様の傾向がみられた。

労働時間別に栄養摂取状態を検討すると表11のよう になった。男女とも労働時間が長いほど、摄取総熱量 は大きくなって招り、また複合含水炭素も同様の傾向 がみられた。蛋白質、脂肪抒よび単純含水炭素の摂取 量は、各群で多少の差はあるが大差ないと考䒚てよい ようであった。しかし、動物性蛋白質拉よび動物性脂 肪の総熱量にしめるエネルギー比をみると、労働時間 が短いもの医どェネルギー比は大きい值となってい た。単純含水炭素のエネルギー比は男女とも労働時間 $4 \sim 8$ 時間群で大きい値がみられたが、複合含水炭素 のエネルギー比は男女とも労働時間 8 時間以上の群が

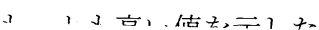

\section{総 括・考 察}

広島県に抢ける都市近郊農村に居住する中高年者の 労㗢負担と健康とくに血液性状との関連について調查 研究した成積についてのべたが、要約すると農業労働 の主体は高令者にかかって预り、耕作面積白全国平均 に比し約半分に止まっていた。これは兼業率が高いこ とに起因しているものと考兄られれ。労働時間は農繁 期の方が農閑期もり平均 2 時間長いが、睡眠時間は農 繁期の方が農閑期に比しむしろ長いようであった。広 島県に抢ける「カキ」養殖業者でも同様の結果が得ら れており ${ }^{1)}$ 、人間が労衝過重になったとき、その生命維 持のための生活のホメオスターンスともいえるもので あろう。身体状況調査では、体調不良のものがかなり 多く、大半をしめていたが、この地区では何らかの形 で治療を行なっているものが多かった。罹病疾患とし ては、循環器疾患、消化器疾患、代謝疾患、骨・関節 疾患が多く又られ、農夫症陽性者は $20 \%$ 以下で比較的 低率であった。高令者（70才以上）についての調査で は、起床、就寝時間は予想より抢そいものが多く、労 働については $80 \%$ が何らかの労㗢について招り、大半 は農作業であった。社会的活動はかなり低調で老人ク ラブへの積極的参加も少ないようであった。体調不良 
者は75\%に達し、その大多数が治療を受けているよう であった。主な罹病疾患は循環器疾患、骨・関節疾患、 白内障が主なものであり、中年者とはやや異った傾向 がみられた。体動不自由者は男性 $7.4 \%$ 、女性 $9.3 \%$ で あり、主な理由は心臓疾患、神経痛、肝障害、脳卒中 で、狭義のねたきり老人は $1.1 \%$ であった。

以上の結果より、中高年者の健康状態は労働時間之 摂取栄養量が関連をもつことが考兄られたので、この 点について追求してみると、労働時間の短いもの（4 時間以下）は男女とも代謝障害および肝障害が問題で あり、動脈硬化性血管障害の Risk factor が多くみら れた。栄養摂取状態では動物性食品の過食の傾向が あった。労働時間が $4 \sim 8$ 時間および 8 時間以上のも のでは、動脈硬化性血管障害の危険因子もかなりみら れるが、高血圧、心電図虚血性変化、貧血、コリンェ ステラーゼ低下等が目立ち、循環器系疾患に注意する 必要があるように思われた。また貧血、コリンェステ ラーゼ低下等農薬との関連も否定できないように考兄 られる変化もみられた ${ }^{13)}$ 。栄養調査成積では、動物性食 品の摄取は労働時間 8 時間以上のものがもっとも少な く、反対に労働時間が増加するほど, 複合含水炭素摂 取量は増大して打り, 単純含水炭素の摄取は労働時間 $4 \sim 8$ 時間のものに多くみられた。

農業従事者の労動負担と血液性状を検討するには、 労働後の一過性の変化 2 (2) をみる必要もあるが、日常 労働と血液性状の関連を長期的に観察することも大切

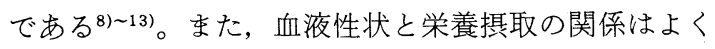
知られているが14) 18)、労働、栄養、血液性状 3 者の関 係を同時に検討した報告は少ない10)。

今回の調查で長期的見地に立って労働負担と関連が あると考兄られた異常は高血圧、心電図虚血性変化、 貧血、コリンェステラーゼ低下等であり、逆に労働負 担の少ないものでは代謝障害と肝障害が目立った。こ れらの機序については不明な点も多いが、過労、食生 活、労働条件、遺伝、地域性等多数の要素が関与して いるものと考兄られ、健康維持のためにはこれらの予 防ないし除去が必要である。

\section{結語}

都市近郊村農居住者の労働負担と健康、とくに血液 性状について調査研究を行なった。その結果、労働に より影響をうける身体異常は高血圧、心電図虚血性変 化、負血、コリンェステラーゼ低下等であり、逆に過 少労働による影響は代謝疾患および肝障害ではないか
と考光られた。また栄養摂取との関連について同時に 検討すると、労衝負担の多いものはそのエネルギー不 足を複合含水炭素で扣ぎなって抢り、過少労働のもの は動物性食品摂取が多く、上記のような障害をもたら すのではないかと考光た。な招、これらに関する知見 はまだまだ充分でなく、農業労働と、さらに農外労働 による影響や、それぞれの栄養摂取との関連について 追求する必要があると考觉ている。

$$
\text { 文献 }
$$

1）高科成良：沿岸漁業者の生産および生活労働に関する研究. 農林水産省特別試験研究費補助金に上る研究報告書（昭和57 年度) : 23 37, 1983.

2) 望月満美子他：農村に抢ける血液性状の分布ならびに変動 に関する研究. 日農医誌30(1)：91 104， 1981.

3) 大島壽美子他：血清コレステロールの加令並びに季節変動. 栄養学雑誌31(5) : 199 203, 1973.

4 ）玄場昭夫：体液成分の日内変動. 臨床病理 22 (臨時号)： 59 81, 1974 .

5 ) 内田壱夫：血清化学成分の日差ならびに季節変動. 臨床病理 27(11) : 1042 1048, 1971.

6 ）上田忠子他：養虫労働の実態と作業従事者の労働負担に関 する研究. 日農医誌32(2)：117〜132, 1983.

7 ）海塩毅一他：農村に打ける血液性状の変動と推移に及ぼす 環境および就労形成の影響に関する研究. 日農医誌30(1)： 65 79, 1981.

8 ）磯村孝二他：長野県八千穂村における血液性状上りみた健 康の基礎的指標に関する研究. 日農医誌30(1)：80～90, 1981.

9 ) 中村正：農村における血液性状よりみた健康の基礎的研 究. 日農医誌30(1)：115～118, 1981.

10）高科成良：広島県農村における血液性状よりみた健康の基 礎的指標に関する研究. 日農医誌30(1)：105 114， 1981.

11）菅谷 趁他：農業生産構造と健康障害に関する研究一単作 地区, 複合経営農家および漁村地区における健康調査のまと め一日農医誌32(2)：1７，1983。

12）杉山一教他：新潟県に打汀る農業生産構造と婦人農業従事 者の健康障害に関する研究. 日農医誌32(2)：8～22, 1983.

13）市川英彦他：季節別に久た長野県婦人農業従事者の健康・生 活に関する研究. 日農医誌32(2)：23～36, 1983.

14）三好 保他：摂取栄養之血液性状の正準相関分折. 日農医誌 33(1) : 46 49, 1984.

15）三好 保他：農山村婦人の摂取栄養と血液性状 1 . 貧血の ない農山村婦人について。四国公衛誌14：7１1，1974.

16）石原辰雄：漁村住民の血液学的ならびに栄養学的調査. 日本 公衛誌18(1)：1181１187， 1971.

17）福井忠孝他：農山村婦人の摂取栄養と血液性状. 日本公衛誌 16(11) : 25, 1969.

18）内田昭夫他：農村婦人の貧血に関寸る研究. 公衆衛生 $34(3)$ : 152 159, 1970. 


\title{
Workload and Health of Farmers of Middle Age or Over In the Suburbs of a City of Hiroshima Prefecture With Special Reference to Blood Test Findings
}

\author{
Seiryo TAKASHINA*, Yoshitaka SEIKIGUCHI*, Toyofumi MITSUYAMA*, \\ Hidetaka SENO*, Sachihiko GOMYO*, Kazuhiko HATTA*, \\ Sachihiro YOKOTA*, Naoki MORITA*, Yasuyuki YOKOZAKI* \\ and Masao DOI*
}

A questionnaire was conducted on the living and working conditions of inhabitants in the suburbs of a city in Hiroshima Prefecture. Respondents received medical and nutritional examinations. A summary of our findings is as follows :

Those persons who are apparently overworking themselves eke out their energy deficiency by taking diets rich in carbohydrate complex. Their major health problems are hypertension, ischemic changes in ECG, anemia and lower cholinesterase activity.

There were indications that agricultural chemicals have harmful effects on the health of the examinees.

In contrast, many of those who work less consume large - even excessive-amounts of animal proteins and fats. Among them prevail liver failxure and metabolic disorders.

In either group of the people examined, there was amundant evidence to show that they are at risk of developing arteriosclerosis.

These findings should be taken into consideration when a health control program is implemnted.

* Department of Internal Medicine, Horishima General Hospital, Hiroshima 